\title{
Simulation modeling of the power supply system of the coal mine excavation area with facts devices
}

\author{
Vyacheslav Voronin ${ }^{1}$, Fedor Nepsha ${ }^{1 *}$, Andrew Kulikov ${ }^{1}$, Anton Korneev ${ }^{1}$, and Anastasia \\ Khasanova $^{1}$
}

${ }^{1}$ T.F. Gorbachev Kuzbass State Technical University, 28 street Vesennyaya, Kemerovo, 650000, Russian Federation

\begin{abstract}
The introduction of technologies for active-adaptive control of the operating modes of the power supply systems of coal mines can contribute to an increase in the energy efficiency of coal mining. Highresponse FACTS devices of the second generation can be used for dynamic reactive power compensation, voltage regulation and limitation of current and voltage harmonic components in conditions of sharply variable electrical loads of mining machines at a breakage face. Evaluation of the effectiveness of the implementation of FACTS devices in the power supply systems of coal mines can be performed using simulation methods.This article discusses the main approaches to the development of a simulation model of a power supply system of a coal mine, mining equipment and FACTS devices. The main results of modeling the joint operation of mining machines are shown. Conclusions about the effectiveness of the use of FACTS devices in the extraction area of a coal mine are made.
\end{abstract}

\section{Introduction}

According to the program for the development of the coal industry in Russia for the period up to 2035 [17] the coal demand has to increase by the value up to $13.95 \%$ (optimistic scenario). The program also includes the technical re-equipment and intensification of coal production by 2025 . The implementation of these plans will lead to an increase in the power consumption of coal mines, and therefore, in order to reduce the prime-cost of coal mining, it becomes important to increase the energy efficiency of coal mining. To achieve this aim, it is necessary to use modern devices for intelligent control of power flows in power supply systems (PSS) of coal mines, the assessment of the effectiveness of the implementation of which is devoted to this work.

The development of power electronics has led to the introduction into electrical networks of a large number of frequency converters used for frequency regulation of an electric drive, as well as for the design of devices for flexible control of electrical network modes - second generation FACTS devices. The main feature of such devices is their high

\footnotetext{
${ }^{*}$ Corresponding author: nepshafs@gmail.com
} 
operation speed, which allows to use them for reactive power compensation (RPC), harmonics filtering and voltage regulation in electrical networks with dynamic load.

The work of consumers with a sharply variable nature of power consumption can be accompanied by the load jumps, which causes the voltage deviations at the network nodes (voltage fluctuations and voltage dips) and negatively affects the operation of other power consumers.

Traditional unregulated or step-controlled reactive power compensation devices (RPCD) do not have sufficient operation speed to respond to dynamic electric load, which leads to a decrease in the effectiveness of RPC and voltage regulation in such electrical networks.

The second generation FACTS devices are fast enough to operate in these environments. A lot of works are devoted to dynamic compensation of reactive power, for example, [1-6]. Despite the fact that the widespread adoption of FACTS devices is hindered by the high price and the lack of a methodology for selecting parameters and sizing of devices for dynamic RPC, currently it is possible to achieve cost-effective solutions for RPC using a combination of dynamic and traditional RPCD [1].

\section{The Problem Statement}

The PSS of coal mines are characterized by sharply variable electrical loads. The work of the mining equipment of the coal mine excavation area takes place in the intermittent periodic duty operation mode with frequent starts and stops. The load of electric drives of mining machines is stochastic and is influenced by many random factors: change in the resistance of coal to cutting; the presence of solid inclusions in the destroyed formation; change in conveyor traffic flow. In this regard, for the development of measures for RPC in PSS of excavation areas of coal mines, it is advisable to consider the use of dynamic RPCD. Prospects for the implementation of FACTS devices in PSS of coal mines were considered in $[7,8]$.

To assess the efficiency of using FACTS devices in coal mines, as well as to develop a methodology for choosing their parameters and locations, it is necessary to develop a simulation model of the PSS of the excavation area and mining equipment. To simulate the dynamic nature of power consumption, the simulation model must take into account the stochastic nature of the load change and the dynamics of the electric drive.

In the literature, there are a number of simulation models of excavation areas of coal mines and related equipment used for different purposes:

the paper [12] presents a simulation model of the power supply scheme for the mining area of the «Polysaevskaya» mine of «SUEK-Kuzbass» JSC, designed to assess the power consumption of the mining area equipment, power losses in the mine's distribution network and the power factor. However, the presented simulation model does not take into account the dynamics of the operation of electric drives of mining machines and the sharply variable nature of their electrical loads;

in the thesis [11], a simulation model of the main technological equipment and PSS of the mining area of the «Polysaevskaya» mine of «SUEK-Kuzbass» JSC was developed, designed for the same tasks as the model [12]. This model makes it possible to take into account the starting properties of the electric drive, however, it also does not take into account the uneven nature of the power consumption of mining machines in operating mode;

in the paper [13], a simulation model of a multi-motor electric drive system of a longwall shearer for researching the starting properties of an electric drive is presented. This model does not allow to obtain a sharply variable nature of the shearer load in the working mode; 
in the monograph [14], a detailed simulation model of the cutting and haulage electric drive of the UKD 300 shearer was developed for the study of the automatic control of the mining shearer. This model takes into account the dynamics of the electric drive and the uneven nature of the power consumption of the shearer, however, the model is considered in isolation from the PSS and other mining machines of the excavation area. In addition, the monograph did not study the dynamics of reactive power consumption;

the papers [15-16] present a simulation model of the shearer's electric drive and control system for the study of electrical and mechanical processes in the shearer and the automatic control system. This model takes into account all the main factors that determine the operating modes of the shearer, however, it also considers it in isolation from other mining equipment. In these papers, no attention is paid to the analysis of the nature of reactive power consumption.

Thus, the results presented in the listed works do not allow assessing the energy efficiency of the PSS of the coal mine excavation area in the dynamic modes of operation of mining machines. In view of the above, it is necessary to develop simulation computer models of the electrical complex of excavation areas, which make it possible to assess the operating mode of the PSS with a sharply variable nature of electrical loads and the effectiveness of measures for RPC. The simulation results can be used for the technical and economic assessment of the dynamic RPC in the conditions of coal mines, as well as for the formation of general approaches to the development of such measures.

Note that computer simulation is also necessary to create adequate mathematical models, which together with the information model make it possible to create a digital twin [18] sufficient to perform the following actions: reliable display of the state of the object in real time; reliable prediction of object behavior under normal and abnormal operating conditions; reliable generation of control actions on the object.

\section{Modeling the power supply system of the excavation area}

\subsection{Description of the simulation object}

An excavation area of one of the coal mines of the Kemerovo region was selected as the object of research. The mechanized complex of the mining area includes: Eickhoff SL 900 shearer; longwall conveyor SH PF 6/1142; reloader ST PF 6/1342; crusher SK 1114; auxiliary electric motors.

The structural scheme of the distribution network of the excavation area is shown in Fig. 1.

The development of the simulation model was carried out in the Matlab - Simulink software environment. 


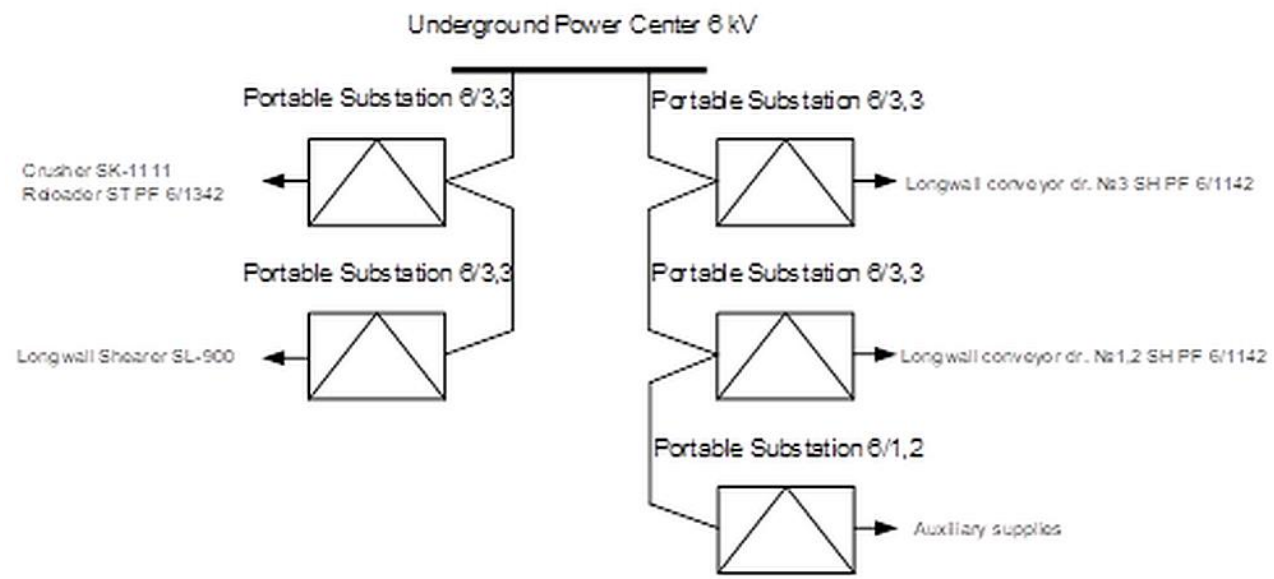

Fig. 1. Structural scheme of an excavated area of a coal mine

\subsection{Modeling the electrical complex of a coal mine in Matlab - Simulink}

In fig. 2 shows the developed simulation model of the PSS of the excavation area of a coal mine.

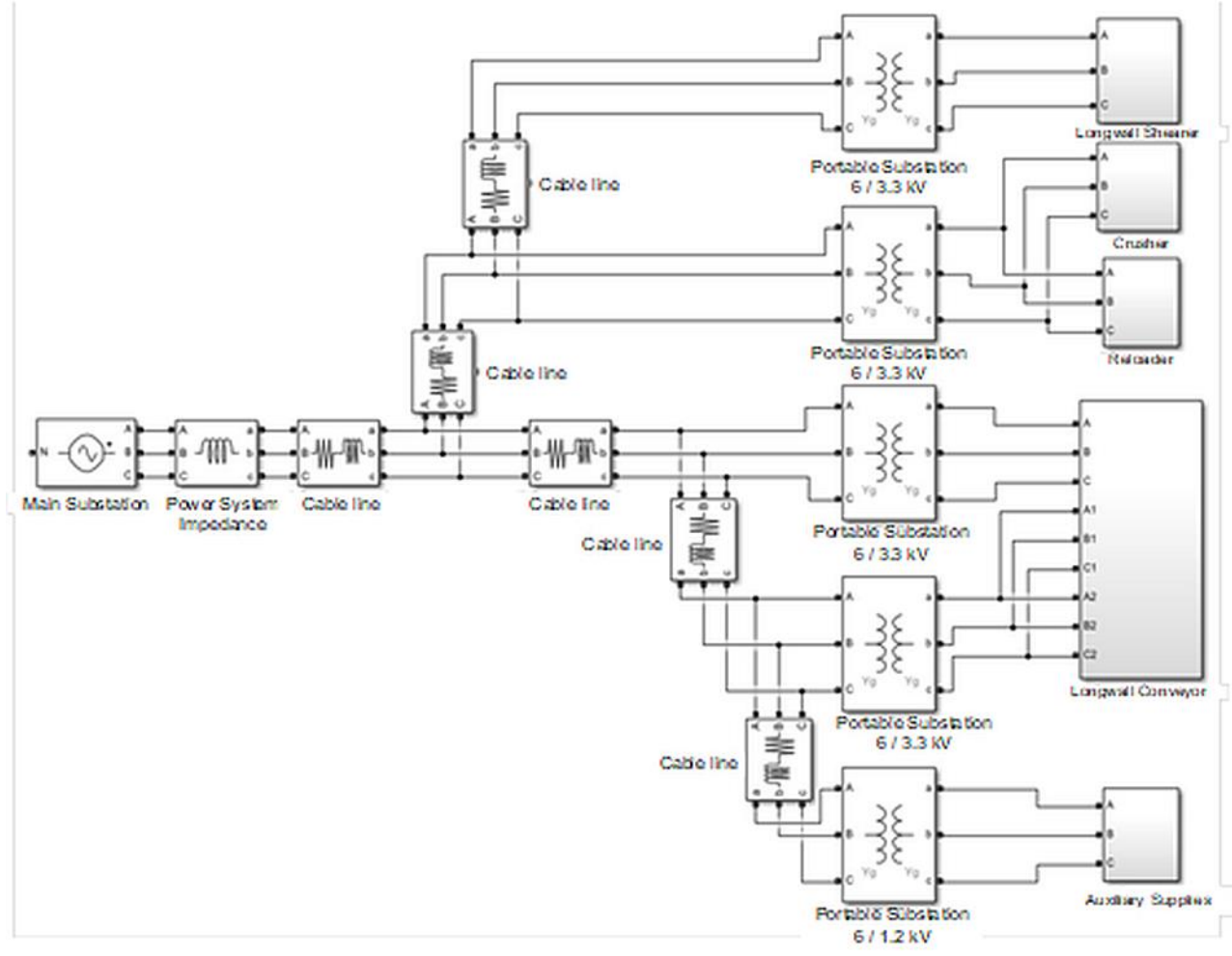

Fig. 2. Simulation model of the PSS of a coal mine excavation area

The main elements of the PSS of the excavation area are represented in the model by the following blocks: 
- The power center is modeled using the Three-Phase Programmable Voltage Source block. This element implements a balanced three-phase voltage source of $6300 \mathrm{~V}$.

- The cable network is modeled by the Three-Phase Series RLC Branch blocks. This block allows you to take into account the resistance of the cable lines of the distribution network of the coal mine.

- Portable substation (PS) $6 / 3.3 \mathrm{kV}$ and PS $6 / 1.2 \mathrm{kV}$ are modeled using the «ThreePhase Transformer (Two Windings)» blocks. This element simulates the operation of a three-phase two-winding transformer that feeds the equipment of the breakage face. The calculation of the parameters of these blocks was carried out based on the methodology presented in [20].

A part of the simulation model from the PS to the three-phase load is assembled into a subsystem. As an example, Fig. 3 shows a fragment of the simulation model of the head drive stations of the longwall conveyor.

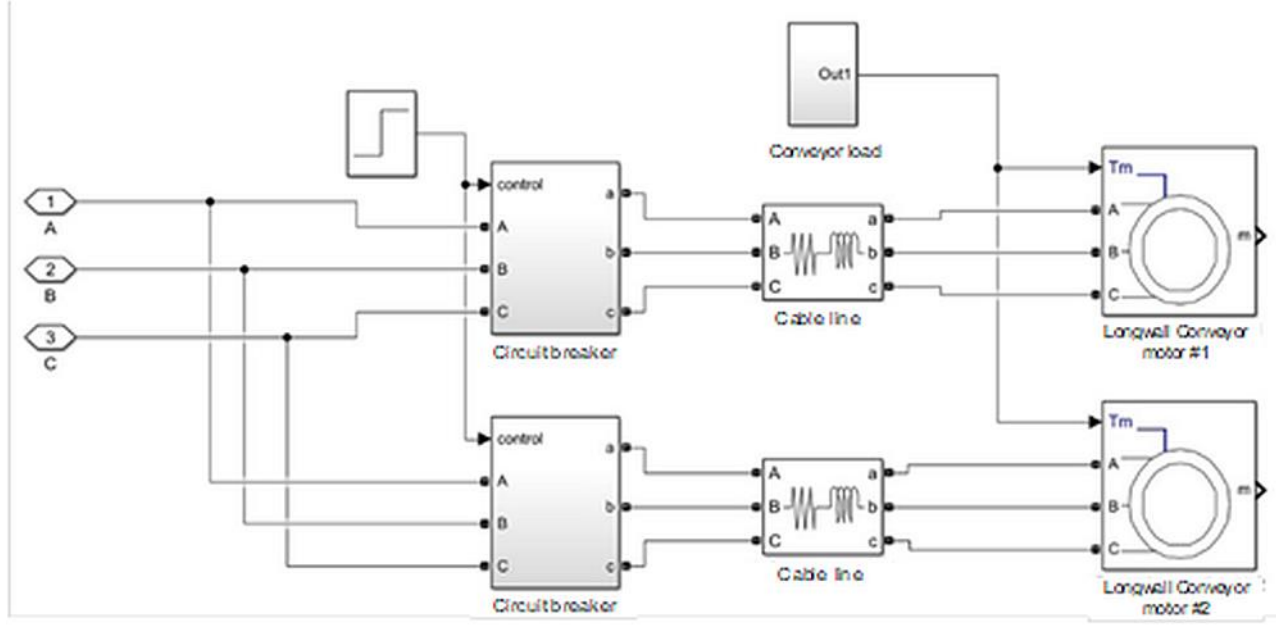

Fig. 3. Simulation model of the head drive of the longwall conveyor

The main elements of Fig. 3 are represented by the following blocks:

- Breakers are modeled using the "Breaker" block. This block is used for switching the circuit and can be controlled by an external input signal ("control" input).

- The electric drive of mining machines is modeled using the "Asynchronous Machine SI Units" block. The unit is a three-phase asynchronous machine. The calculation of the parameters of these blocks was carried out based on the technique presented in [21].

To take into account the dynamic nature of changes in the electrical loads of the electric equipment of the breakage face in the simulation model, a generator of a random motor torque was used for the shearer's cutting electric drives and the longwall conveyor.

The load of the longwall conveyor is set by a random change in the traffic flow. To implement the random process, the random function filtering method was used, which was considered in detail in [10] (block "Load on the conveyor", Fig. 3).

The load of the shearer's cutting drive is determined by random changes in the cutting resistance of coal and the presence of solid inclusions in the seam. Simulation of a stationary random process describing the variability of the material's resistance to cutting within the excavation strip was carried out based on [9].

\subsection{Modeling reactive power flow control devices}




\subsubsection{Capacitor banks}

High-voltage explosion-proof mine capacitor unit (EPMCU) is designed to compensate for reactive power in electrical networks of underground PSS of mines. Structurally, the EPMCU consists of two main parts: a vacuum circuit breaker section and a capacitor bank. EPMCU can have several stages of regulation and an automatic control system. The simulation model of the regulated EPMCU is shown in Fig. 4.

The EPMCU simulation model consists of a reactive power controller and regulation stages (switch-capacitor bank units). The EPMCU is controlled by the power factor. The speed of the capacitor unit is determined by the turn-on delay and blocking of the stage after it is turned off for the duration of the capacitor discharge (300 seconds). The development of the operation algorithm of the reactive power controller EPMCU is considered in [22].

This paper considers the use of EPMCU $6 \mathrm{kV} \mathrm{3 \times 1000} \mathrm{kvar;} \mathrm{connection} \mathrm{point} \mathrm{-}$ underground power center busbars (Fig. 1).

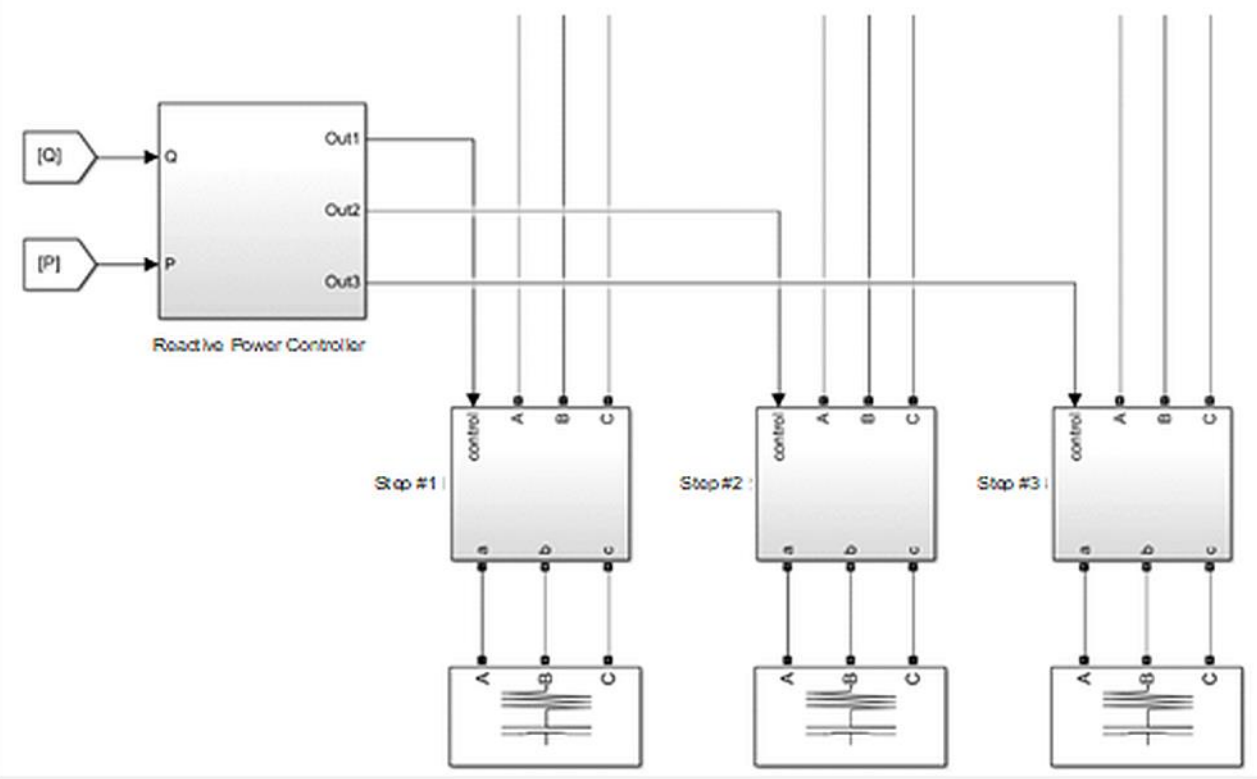

Fig. 4. Simulation model of EPMCU in Matlab - Simulink

\subsubsection{D-STATCOM}

For dynamic compensation of reactive power and filtering of harmonic components, the model uses the D-STATCOM device, the diagram of which is shown in Fig. 5. In this work, we used the ready-made D-STATCOM model presented in [19].

The D-STATCOM includes a voltage source inverter and capacitor. A filter is connected at the output of the inverter to limit the higher harmonics of the currents injected into the grid. The D-STATCOM uses a vector control method with vector PWM. The controller consists of two parts: voltage controller - to maintain a constant voltage in the DC link of the inverter; current controller - for reactive power compensation and filtering of higher harmonics. 

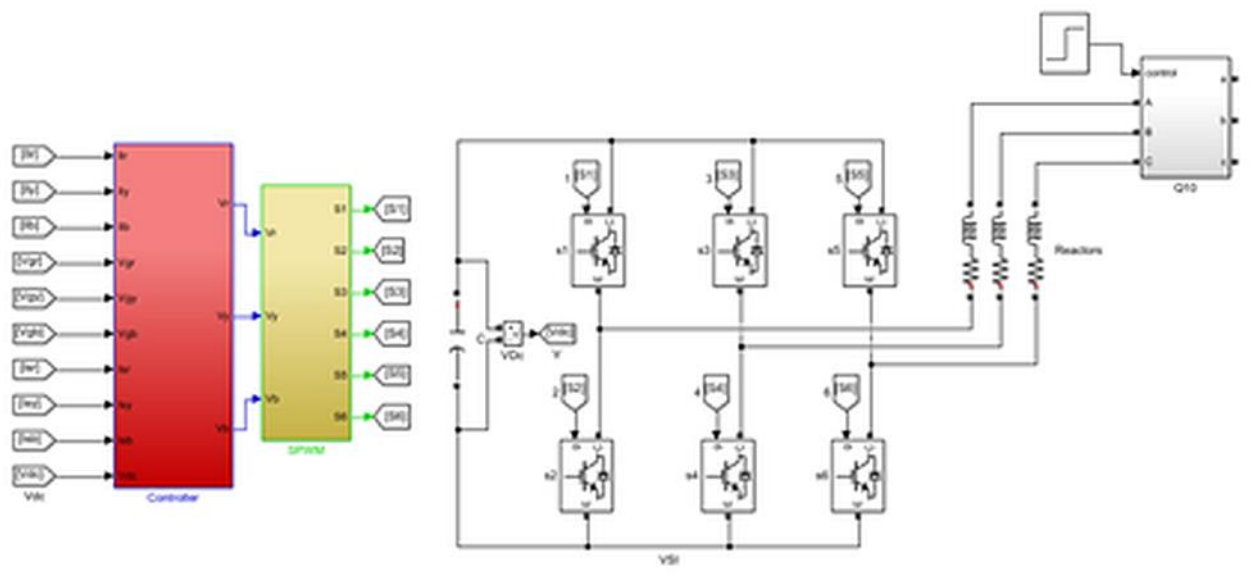

Fig. 5. Simulation model of the D-STATCOM in Matlab - Simulink

\subsubsection{Dynamic Voltage Restorer}

Dynamic Voltage Restorer (DVR) is a device for compensating and mitigating voltage disturbances. DVR is connected in series and injects the desired voltage to the load-side when there is a voltage disturbance at the supply-side. The simulation model of the DVR is shown in Fig. 6. In this work, we used the ready-made DVR model presented in [23].

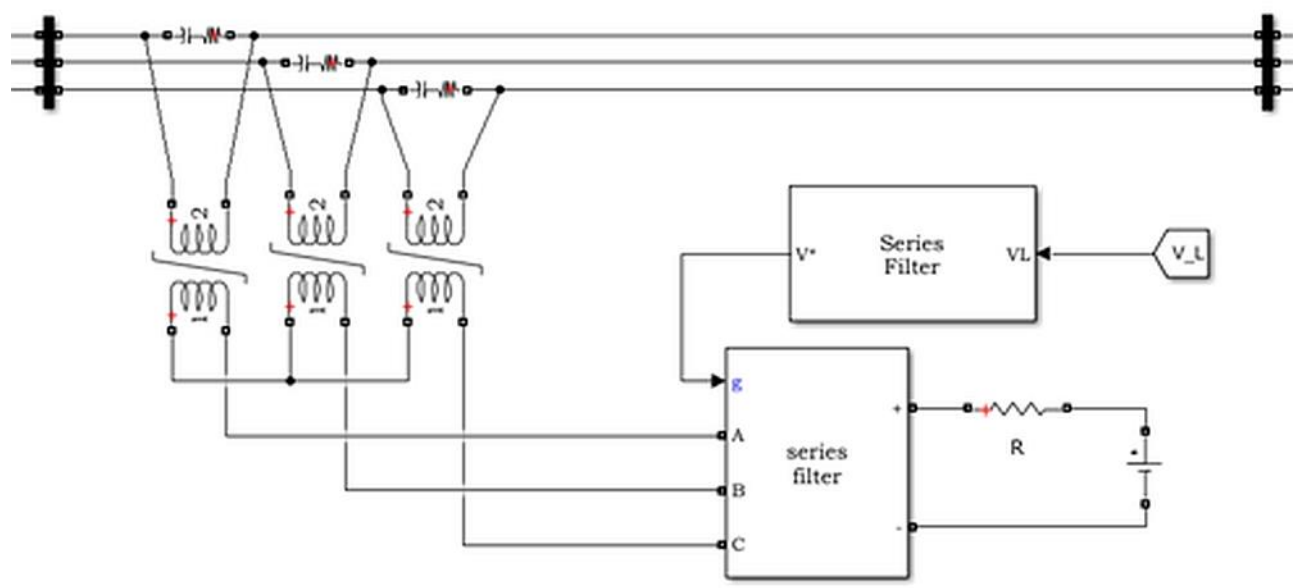

Fig. 6. Simulation model of the DVR in Matlab - Simulink 


\section{Results and discussion}

\subsection{Use case 0: without reactive power compensation}

The fig. 7 shows the results of modeling the total reactive power consumed by the main equipment of the excavation area, without RPC devices.

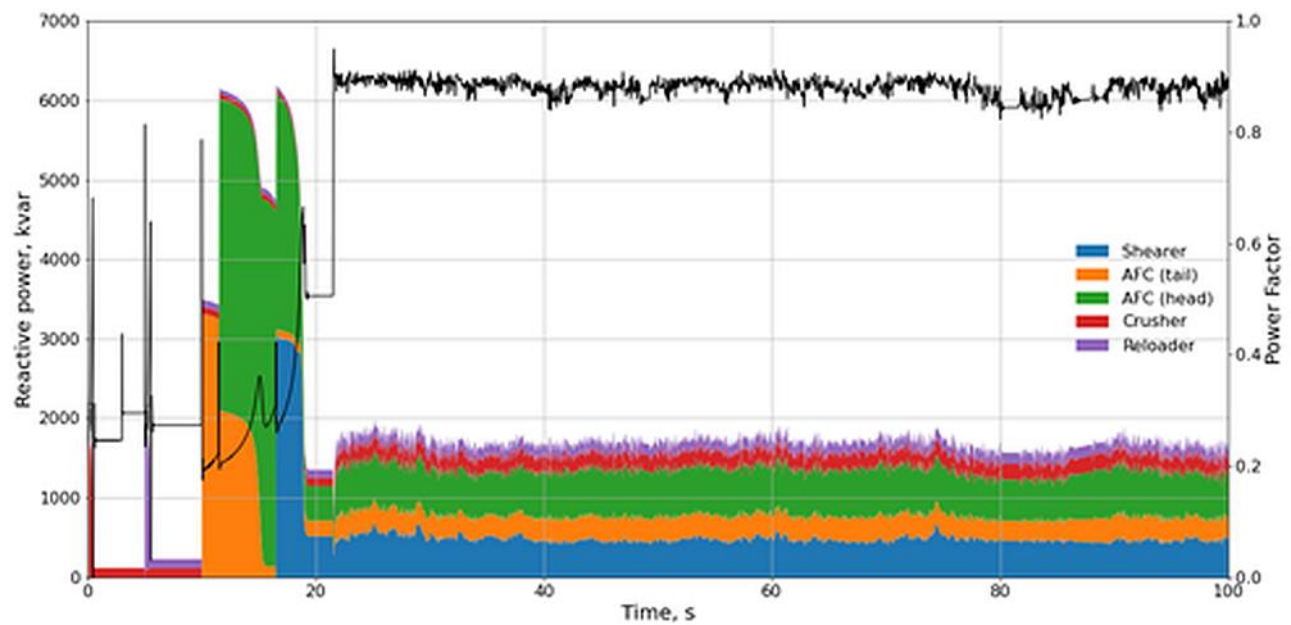

Fig. 7. Reactive power and power factor plot of the excavation area

The fig. 7 shows the process of starting the mining equipment of the excavation area. Start-up takes place in the following sequence: crusher, reloader, tail drive of the longwall conveyor, head drive of the longwall conveyor, shearer. At 21.5 seconds of simulation, the shearer is notched, then the working mode of the excavation area is simulated.

During the simulation period, the reactive power consumption of the mining area was $58.26 \mathrm{kvar} \cdot \mathrm{h}$ with an average reactive power of $2097.53 \mathrm{kvar}$. The fig. 8 shows the distribution of reactive power consumption for mining machines. The highest consumption of reactive power is observed during the start-up of mining equipment ( $Q$ reaches 7481.92 kvar). The launch of mining machines lasts for 20 seconds, the average power factor in this interval is 0.29 . During operation, the average power factor rises to 0.87 . Accounting for stochastic processes affecting the load on the shearer's electric drive, as well as modeling a random change in the conveyor traffic flow, leads to slightly uneven reactive power consumption in normal operating mode. 


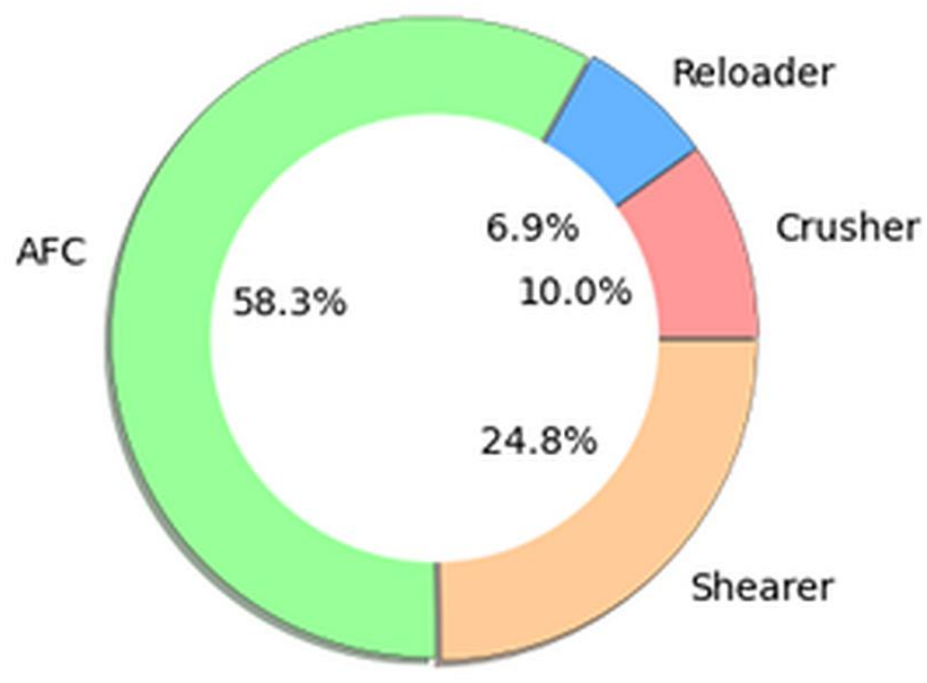

Fig. 8. Pie chart of reactive power consumption of the excavation area

The fig. 9 shows a graph of the voltage change on the underground power center busbars of the $6 \mathrm{kV}$. During starting processes, significant voltage deviations are observed up to $-36.10 \%$. In normal operating mode, the voltage deviation is also large, averaging $11.34 \%$.

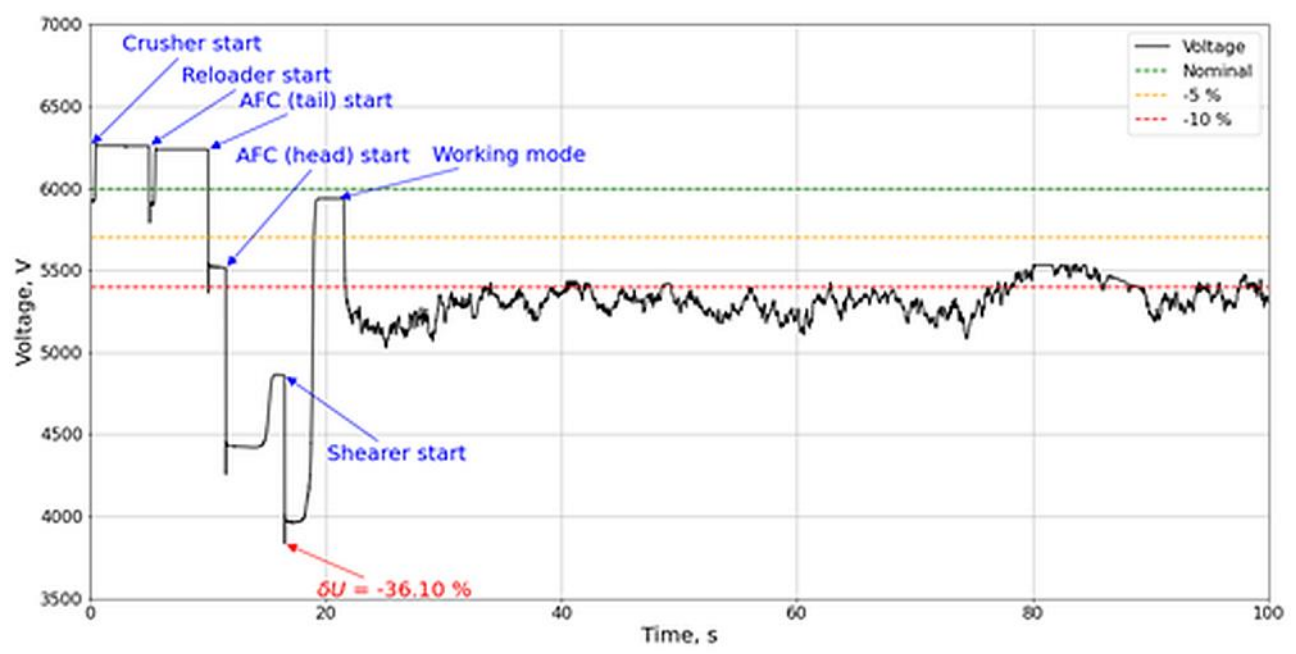

Fig. 9. Voltage plot on the $6 \mathrm{kV}$ underground power center busbars

\subsection{Use case 1: Capacitor bank installation}

In fig. 10, 11 show the results of modeling the operation of the excavation area when installed on the buses of the $6 \mathrm{kV}$ of the automatic EPMCU $3 \times 1000$ kvar. 
The operation of the EPMCU reduces reactive power consumption by $69.86 \%$, the average power factor during the working mode increases to 0.99 , and during the starting mode to 0.34 . Voltage deviations during working mode are reduced to $-6.44 \%$.

Due to the low speed and limited power of the steps, the EPMCU does not have time to quickly respond to starting processes and generate a sufficient amount of reactive power. The maximum negative voltage deviation during start-up is $-33.92 \%$ and does not differ much from the option with the absence of the EPMCU. During start-up processes, the EPMCU reduces reactive power consumption by only $16.75 \%$.

\subsection{Use case 2: D-STATCOM installation}

In fig. 10, 11 show the results of modeling the operation of the excavation area when installed on the buses of the $6 \mathrm{kV}$ of the 3 Mvar D-STATCOM.

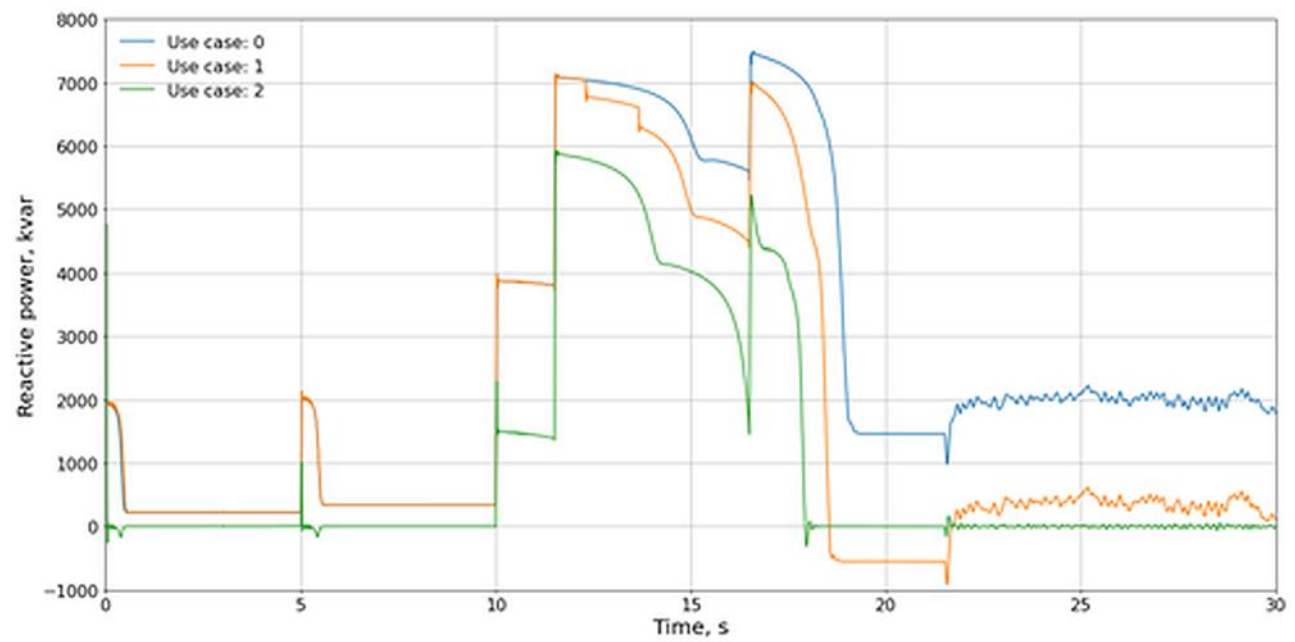

Fig. 10. Reactive power plot of the excavation area during the start-up of mining equipment

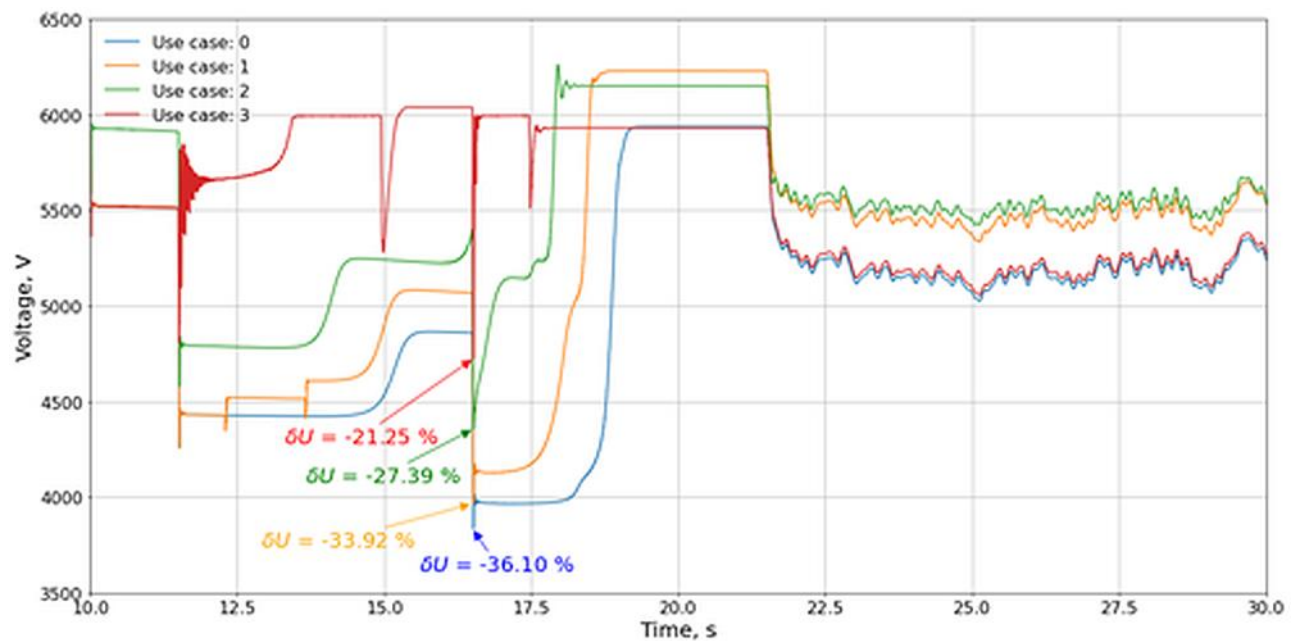

Fig. 11. Voltage plot on the $6 \mathrm{kV}$ underground power center busbars during the start-up of mining equipment 
The operation of D-STATCOM reduces the reactive power consumption for the entire simulation period by $85.2 \%$. The average power factor during the start-up mode increases to 0.79 . The maximum reactive power reaches only $5929.70 \mathrm{kvar}$, which is $20.75 \%$ less than in the absence of D-STATCOM. The maximum negative voltage deviation in the starting mode is $-27.39 \%$, and in the operating mode $-6.04 \%$.

\subsection{Use case 2: DVR installation}

In fig. 11 show the results of modeling the operation of the excavation area with DVR.

The DVR is configured to compensate for the deepest voltage sags during the start-up mode. As follows from Fig. 11, DVR has been shown to be the most effective in voltage regulation. The average voltage deviation during start-up is $-3.11 \%$ which is significantly lower compared to other options. However, the DVR is designed for short-term operation during voltage dips, so it has no effect on voltage deviation during working operating mode.

\section{Conclusion}

In this paper, a simulation model of the PSS of the excavation area of a coal mine was presented, taking into account the dynamic mode of operation of mining machines and the stochastic nature of their electrical load. On the basis of the developed model, an analysis of the reactive power consumption of electric drives of a breakage face was carried out and an assessment of the effectiveness of the use of various RPCD devices was performed.

The analysis showed that the use of a step-controlled capacitor bank unit does not sufficiently limit the voltage drops that occur when starting mining machines. However, the operation of the EPMCU significantly increases the power factor in the normal operating mode of the mining equipment of the excavation area.

The modern D-STATCOM dynamic RPCD device quickly reacts to the growth of reactive power during starting processes and better maintains the voltage level and also allows to provide full compensation of reactive power during the working mode.

However, for limiting voltage dips, the DVR is the most effective solution.

Further research should be aimed at developing a methodology for selecting the sizing and placing of RPC devices in the PSS of the excavation areas of coal mines.

In this paper, the research was sponsored by the Grant of the President of the Russian Federation for the state support of young Russian scientists No. MK-236.2020.8.

\section{References}

1. H.K. Tyll, F. Schettler, IEEE/PES Power Systems Conference and Exposition, 1 (2009)

2. Q. Cheng, J. Chen, Y. Yuan, X. Zhou, Applied Mechanics and Materials, 602, 2840 (2014)

3. V.V. Dabarov, Kompensatsiya reaktivnoy moshchnosti v dinamicheskikh rezhimakh raboty elektrodvigatel'noy nagruzki, 107 (2015) 
4. M.M de Oliveira, M. IEEE PES Transmission \& Distribution Conference and Exposition - Latin America (2016)

5. N.K Saxena, A. Kumar, Electric Power Components and Systems, 45 (18), 2034 (2017)

6. Y. Lee, H. Song, Sustainability, 11, 326 (2019)

7. V.A. Voronin, F.S. Nepsha, Perspektivy innovatsionnogo razvitiya ugol'nykh regionov Rossii. Sbornik trudov VII Mezhdunarodnoy nauchno-prakticheskoy konferentsii, 67 (2020)

8. F. Nepsha, V. Voronin, R. Belyaevsky, V. Efremenko and K. Varnavskiy, E3S Web Conf., 174 (2020)

9. A.V. Zelenkov, Izvestiya Tula State University. Technical science, 10, 196 (2020)

10. V.V. Dmitriev, T.Yu. Polyakova Mining informational and analytical bulletin (MIAB) (2009)

11. A.M. Bondarenko Razrabotka i obosnovanie metodiki opredeleniya udel'nogo elektropotrebleniya tekhnologicheskogo oborudovaniya vyemochnykh uchastkov ugol'nykh shakht, 148 (2021)

12. K.N. Kopylov, S.N. Reshetnyak, S.S. Kubrin, Mining informational and analytical bulletin (MIAB), 12, 40 (2016)

13. S.A. Zagolilo, A.S. Semenov, M.N. Semenova, I.A. Yakushev, Modelirovanie, optimizatsiya i informatsionnye tekhnologii, 8 (2020)

14. V.V. Tkachev, A.V. Bublikov Ispol'zovanie imitatsionnogo modelirovaniya dlya issledovaniya sistemy avtomaticheskogo upravleniya dobychnym kombaynom: monografiya (NMU, Dnipropetrovsk, 2015)

15. D.M. Shprekher, G.I. Babokin, E.B. Kolesnikov, A.V. Zelenkov, Izvestiya Tula State University. Technical science, 2, 514 (2020)

16. D.M. Shprekher, G.I. Babokin, E.B. Kolesnikov, Izvestiya Tula State University. Technical science, 3, 645 (2019)

17. Order of the Government of the Russian Federation from 13.06.2020 N 1582-r On approval of the Program for the development of the coal industry in Russia for the period up to 2035 (2020). Retrieved from http://www.consultant.ru/document/cons_doc_LAW_355241/

18. V.V. Okol'nishnikov, A.A. Ordin, S.V. Rudometov, Trudy XVII Mezhdunarodnoy konferentsii DICR-2019 (2019)

19. MathWorks. File Exchange: official site. - URL: https://www.mathworks.com/matlabcentral/fileexchange/63157-vsi-based-dstatcom?s_tid=srchtitle

20. I.V. Novash, Yu.V. Rumyantsev, Energetika. Izvestiya vysshikh uchebnykh zavedeniy i energeticheskikh ob"edineniy SNG, 12 (2015)

21. O.V. Pantel' Academy Nauchnyy zhurnal na temu: Matematika, Sotsial'nye nauki, Psikhologicheskie nauki, Ekonomika i biznes, Nauki ob obrazovanii, 1 (2015)

22. V.A. Voronin, F.S. Nepsha, Rossiya molodaya: Sbornik materialov XIII Vseros. nauchno-prakticheskoy konferentsii s mezhdunarodnym uchastием (2021) 
23. MathWorks. File Exchange: official site. - URL: https://www.mathworks.com/matlabcentral/fileexchange/51064-series-active-filterdynamic-voltage-restorer-dvr 